\title{
PROF. DR. ZDRAVKO KUČIĆ (1910. - 1961.), ORGANIZATOR BOLNIČKE SLUŽBE U POSLIJERATNOJ RIJECI
}

\author{
PROFESSOR DR. ZDRAVKO KUČIĆ (1910-1961), \\ PROMOTER OF THE HOSPITAL \\ SERVICE IN POST-WAR RIJEKA
}

\author{
Juraj Kučić*
}

SAŽETAK

Rođen je u Bakru II. travnja 1910. Sušačku gimnaziju završio je 1928., a diplomirao je na Medicinskom fakultetu u Beogradu i934. Nakon pripravničkog staža radi kao sekundarni liječnik, potom asistent na Internom odjelu Opće banovinske bolnice kralja Aleksandra I. u Sušaku, a 1940. postaje specijalist interne medicine. Do I943. radi na sušačkom i riječkom Internom odjelu, a po kapitulaciji fašističke Kraljevine Italije odlazi u Narodnooslobodilačku vojsku Jugoslavije (partizane) gdje obnaša visoke dužnosti u vojnom sanitetu.

Nakon demobilizacije iz Jugoslavenske armije 1946. imenovan je šefom Internog i Zaraznog odjela sušačke bolnice, 1948. postaje šef Internog odjela riječke bolnice, a početkom I949. imenovan je primarijusom Internog odjela i direktorom Opće bolnice Rijeka.

Istaknuti je društveno-politički rukovoditelj $i$, uz brojne druge dužnosti u tijelima narodne vlasti, obnaša dužnost načelnika Zdravstveno-socijalnog odjela Gradskoga narodnog odbora Rijeke. Na tom položaju dugogodišnji je organizator poslijeratnoga bolničkog zdravstva grada i kotara Rijeka. Jedan je od najzaslužnijih za osnivanje Medicinskog fakulteta u Rijeci 1955. na kojem je 1958. izabran za docenta, a 1959. za izvanrednog profesora na Katedri za internu medicinu. Umro je u Rijeci 2r. listopada 196r.

Ključne riječi: Zdravko Kučić; povijest medicine; 20. stoljeće; Hrvatska; Sušak; Rijeka

Adresa za dopisivanje: Juraj Kučić, Gimnazijske stube 5, 51000 Rijeka, Hrvatska. E-pošta: jure.kucic@gmail.com. 
Dr. Zdravko Kučić rođen je II. travnja IgIo. u Bakru. Potječe iz stare sušačke obitelji. Njegov otac dr. Juraj Kučić bio je gradonačelnik Bakra i Sušaka, veliki župan Modruško-riječke, Primorsko-krajiške i Osječke oblasti, banovinski inspektor i savjetnik pri banskoj upravi Banovine Hrvatske, a majka Nada rođena Vučić, učiteljica [r].

Osnovnu školu pohađao je u Bakru i Ogulinu, a realnu gimnaziju završio je u Sušaku 1928. Iste godine upisao se na zagrebački Medicinski fakultet gdje je završio prvi rigoroz. Diplomirao je na beogradskom Medicinskom fakultetu 1934. godine.

Nakon reguliranja vojne obveze i pripravničkog staža, u svibnju 1935. zaposlio se kao sekundarni liječnik u Općoj javnoj banovinskoj bolnici kralja Aleksandra I. u Sušaku. Radi na Internom i Zaraznom odjelu pod vodstvom primarijusa dr. Silvija Novaka. Državni stručni ispit polaže 1936., a specijalistički ispit iz interne medicine 1940. pred ispitnom komisijom pri banskoj vlasti Banovine Hrvatske u Zagrebu [2-5].

Do početka rata u travnju 194I. dr. Kučić radi na Internom i Zaraznom odjelu sušačke bolnice i u privatnoj liječničkoj ordinaciji. Mobiliziran kao sanitetski poručnik izbjegao je zarobljeništvo i sredinom svibnja I94I. došao

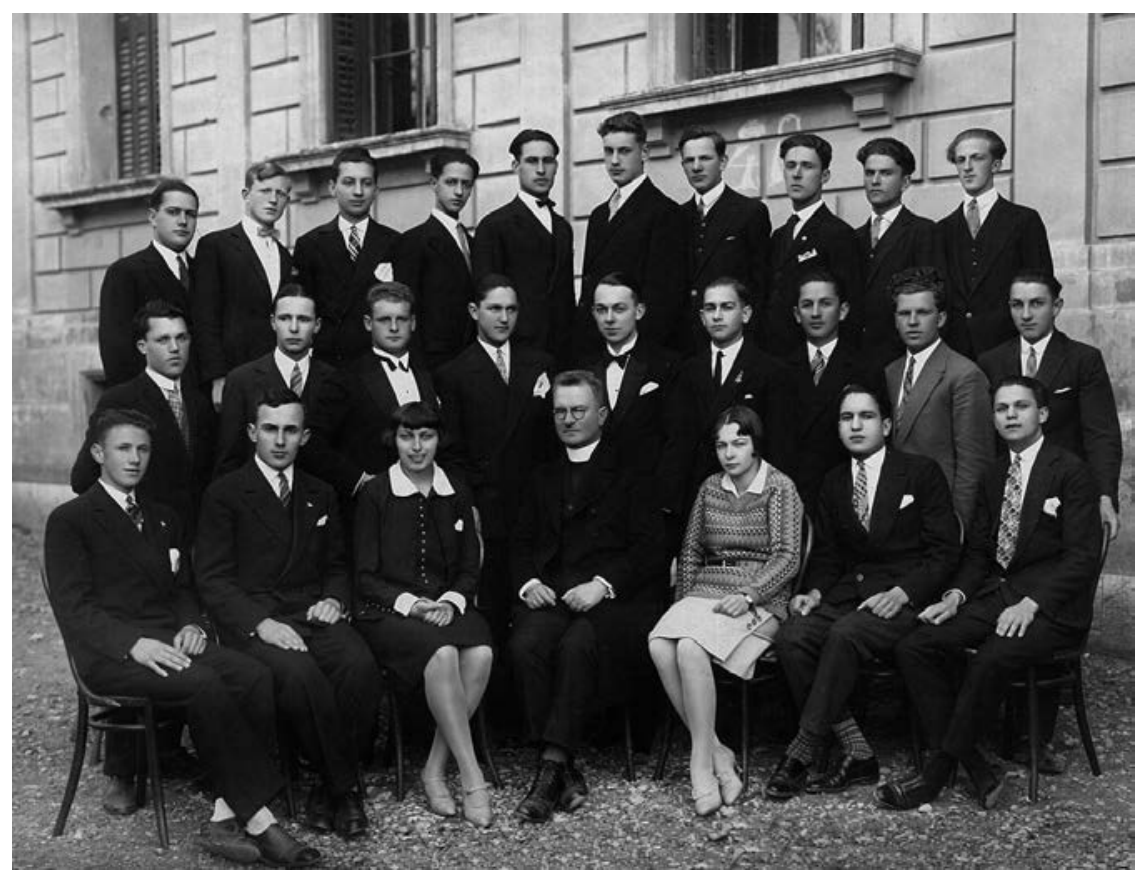

Slika r. Maturanti Sušačke gimnazije s razrednikom, velečasnim dr. Matijom

Pacherom. U prvom redu, prvi slijeva, sjedi Zdravko Kučić, Sušak I928. 


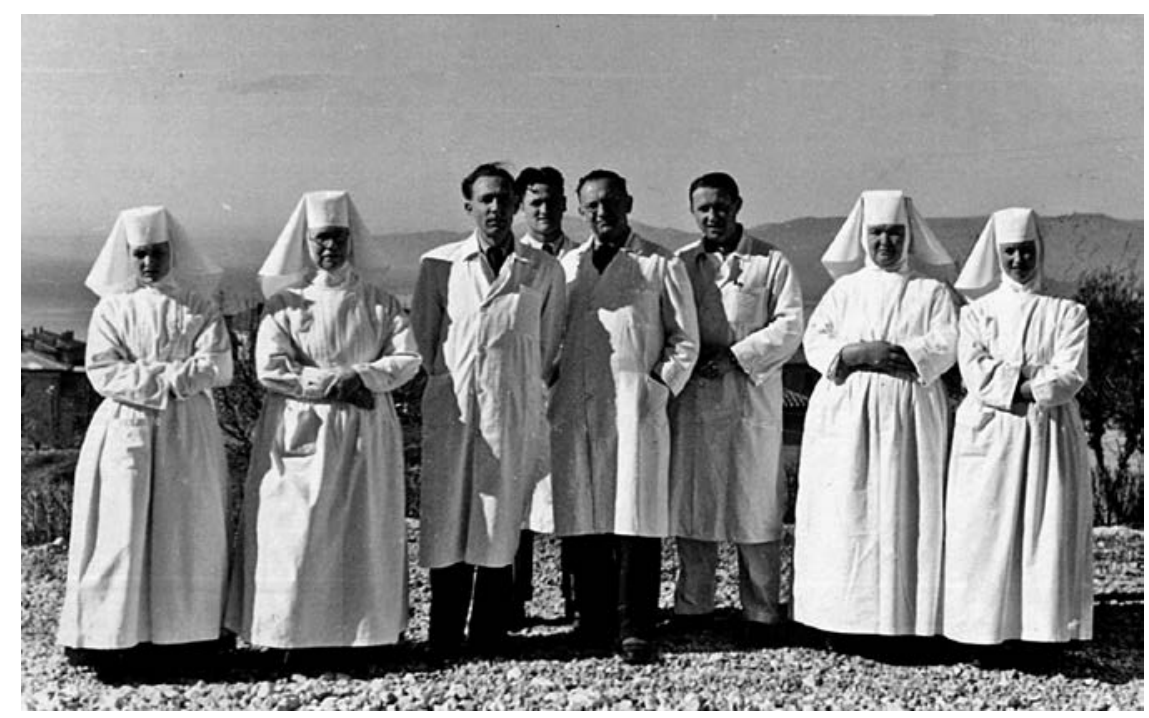

Slika 2. Liječnici i časne sestre milosrdnice Opće javne banovinske bolnice kralja Aleksandra I. u Sušaku 194I. Treći slijeva stoji prim. dr. Silvije Novak, a šesti dr. Zdravko Kučić

u Zagreb gdje su mu živjeli roditelji. Budući da je Sušak okupirala fašistička Kraljevina Italija, vlasti Nezavisne Države Hrvatske ponudile su mu mjesto liječnika specijalista internista u bolnici u Banjoj Luci. Odbio je ponudu i vratio se u Sušak gdje nastavlja s radom na Internom i Zaraznom odjelu sušačke bolnice.

Kao rodoljub i antifašist, u kolovozu I94I. uspostavlja vezu s Narodnooslobodilačkim pokretom (NOP). U gradu punom talijanske vojske i policije, zajedno s osobljem bolnice, ilegalno liječi pripadnike NOP-a. Tako su u studenome 194I. u bolnici liječeni smrznuti partizani nakon razbijanja partizanskog odreda Božo Vidas-Vuk na Tuhobiću. („U odjelu za tuberkulozne bolesnike prozori su bili stalno otvoreni. Došla je i talijanska komisija. Dr. Kučić nas je savjetovao kako trebamo govoriti. I mi smo rekli da smo pali u more i prehladili se" - citat Ivana Felkera). Ilegalno se liječilo i po kućama simpatizera NOP-a. U sušačkoj bolnici utočište su našli oni koji su zbog rase, vjere i političkih uvjerenja bježali pred progonima u NDH (Židovi, Srbi i Hrvati antifašisti) [5-7].

Zbog antifašističkog djelovanja cjelokupnoga bolničkog osoblja i velikih vojnih gubitaka na goransko-ličko-kordunaškom ratištu, talijanske vlasti u lipnju 1942. doslovce su ispraznile bolnicu. Bolesnici se premještaju u riječku bolnicu, a svi liječnici i osoblje koje nije rođenjem iz hrvatskih krajeva 
pripojenih Kraljevini Italiji, protjeruju se u NDH. Tada je, uz ostale liječnike Hrvate, protjeran i primarijus Silvije Novak, korijenima Primorac rođen u Zagrebu, a dr. Kučić premješten je u talijansku riječku Bolnicu Svetog Duha (Ospedale civile di Santo Spirito di Fiume) gdje od 8. rujna 1942. radi na Internom odjelu kod prof. Jacchija. Sušačka je bolnica sve do kapitulacije Italije 8. rujna 1943. talijanska vojna bolnica. Koristeći talijansko rasulo, dr. Kučić odlazi u partizane $[2,5-7]$.

Od rujna 1943. do siječnja 1946. obnaša visoke dužnosti u sanitetskoj službi Narodnooslobodilačke vojske i Jugo-

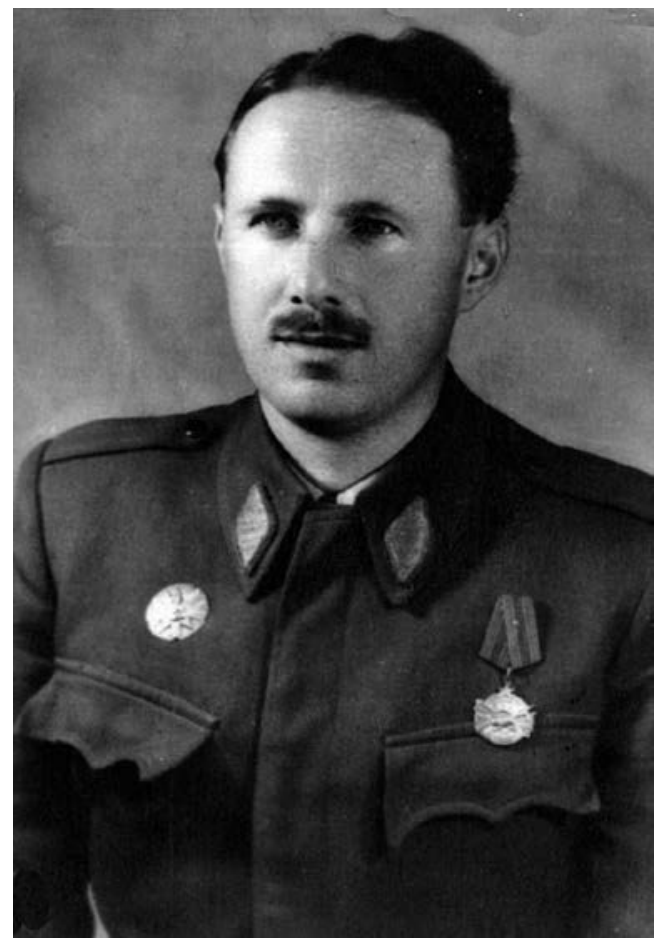

Slika 3. Načelnik Saniteta pozadine Četvrte jugoslavenske armije, major dr. Zdravko Kučić, Ljubljana, lipanj 1945. slavenske armije: referent Saniteta Osme kordunaške divizije, član Sanitetskog odjeljenja Glavnog štaba Hrvatske, načelnik Saniteta Četvrtog i jedanaestog korpusa NOVJ-a i načelnik Saniteta pozadine Četvrte jugoslavenske armije. Hrabrost i organizacijske sposobnosti u ratnim vremenima dolaze kod njega do izražaja te je više puta odlikovan i unapređivan. Rat završava u činu majora i rezervnog potpukovnika JA [8,9].

Po oslobođenju Sušaka i Rijeke 3. svibnja 1945. bolnice pod Vojnom upravom Jugoslavenske armije pretrpane su bolesnicima i ranjenicima koji se liječe i u prihvatnim bolnicama u Kraljevici, Crikvenici, Lovranu i Ičićima.

Bolnice, napose sušačka, dočekale su oslobođenje grada vandalski opustošene. U katastrofalnom su stanju; osim osnovnih lijekova, instrumentarija i sanitetskog materijala dobivenih iz vojnih rezervi, nedostaje sva oprema, a na odjelima je stalna nestašica sapuna i dezinfekcijskih sredstava. 
Početkom 1946. sušačka bolnica postaje civilna, sada pod nazivom Okružna bolnica Sušak, a u njoj počinju ponovno raditi demobilizirani liječnici na odjelima na kojima su radili prije rata.

Treba se prisjetiti prvih poslijeratnih šefova odjela i njihovih asistenata:

- Kirurški odjel: prim. dr. Janko Komljenović, asistenti dr. Davor Sotler i dr. Branko Fink (1946.).

- Ginekološko-porođajni odjel: dr. Davor Perović, bolničar Rafael Smojver (svibanj i946.)

- Dermatovenerološki odjel: prim. dr. Ante Vukas (siječanj I947.)

- Otorinolaringološki odjel: prim. dr. Jakov Bakotić (svibanj 1946.)

- Interni i Zarazni odjel: dr. Zdravko Kučić (veljača i946.)

- Urološki odjel iz Zagreba formira dr. Zlatko Šestić (travanj I947.)

- Rendgen kabinet osniva dr. Marija Richtman iz Zagreba (lipanj 1947.)

Sušačka bolnica ima prosekturu koju vodi dr. Zdravko Kučić, ljekarnu vode časne sestre milosrdnice, a centralni laboratorij ne postoji.

Nakon kapitulacije Italije dio fašistički usmjerenih zaposlenika riječke bolnice napušta Rijeku, a u rujnu I947., nakon pripojenja Rijeke FNRJ, slijedi egzodus talijanskog stanovništva (esuli i optanti). U Italiju odlaze i gotovo svi liječnici, medicinske sestre, administrativno i tehničko osoblje riječke bolnice. Premda Rijeka od svibnja I945. do rujna I947. nije de iure u sastavu FNRJ, Ministarstvo narodnog zdravlja NR Hrvatske od i946. do I948. administrativnim rješenjima (dekretima) popunjava riječku bolnicu hrvatskim osobljem, većinom iz zagrebačkih bolnica.

Evo imena i prezimena prvih poslijeratnih šefova odjela riječke bolnice i njihovih asistenata (u zagradama su navedena mjesta odakle su došli i/ili vrijeme kad su osnovali bolnički odjel):

- Kirurški odjel: prim. dr. Ante Medanić (Karlovac, rujan 1946.), asistenti: dr. Ljubica Bosner i dr. Davor Grgurina (I946.)

- Interni odjel: doc. dr. Ante Grgurina (Opatija, I946.), asistent prim. dr. Luigi Martini

- Zarazni odjel: prim. dr. Walter Rukavina (Zagreb, I946.), asistent dr. Vlasta Ribarić (I946.)

- Ginekološko-porođajni odjel (izdvojen iz Kirurškog odjela): prim. dr. Viktor Finderle (1946.)

- Dermatovenerološki odjel: prim. dr. Dušan Jakac (Zagreb, rujan 1946.)

- Pedijatrijski odjel: prim. dr. Ana Jakša (I945. - I947.), prim. dr. Nada Kovačević-Ivanović (Zagreb, rujan I947.) 
- Oftalmološki odjel: prim. dr. Albert Filipović (1945.), asistentica dr. Velinka Švalba (1946.)

- Otorinolaringološki odjel (izdvojen iz Kirurškog odjela): dr. Josip Ružić (Zagreb, 1947.)

- Neuropsihijatrijski odjel. prim. dr. Zvonimir Sušić (Zagreb, lipanj I947.)

- Ortopedski odjel (u sastavu Kirurškog odjela): dr. Zdenko Šporn (Kraljevica, siječanj 1948.)

- Rendgenski kabinet: prim. dr. Berislav Turčić (Zagreb, siječanj 1947.)

- Prosektura: dr. Veljko Bujan (Zagreb, studeni 1946.)

- Ljekarna: dr. Ivo Marušić (Zagreb, studeni 1946.)

- Centralni bolnički laboratorij: dr. Dragica Ciganović (Senj, ožujak I948.)

Nakon ujedinjenja Sušaka i Rijeke I2. veljače 1948. došlo je do spajanja sušačke i riječke bolnice u Bolnicu Sušak-Rijeka. Već krajem iste godine dolazi do razdruživanja pa se u jedinstvenom gradu osnivaju Opća bolnica Sušak i Opća bolnica Rijeka.

Nakon demobilizacije 4. siječnja 1946. dr. Zdravko Kučić je šef Internog i Zaraznog odjela sušačke bolnice u razdoblju od I946. do I948., a nakon ujedinjenja Rijeke i Sušaka postaje šef Internog odjela riječke bolnice. Dekretom ministra narodnog zdravlja NR Hrvatske dr. Aleksandra Koharevića, 5. siječnja I949. postaje primarijus, šef Internog odjela (I60 kreveta) i direktor riječke bolnice (932 kreveta), na kojoj dužnosti ostaje do smrti I96r.

Noseći se s golemim teškoćama zbog optiranja talijanskoga medicinskog osoblja i velikog pomanjkanja kvalificiranoga liječničkog i sestrinskog osoblja, nedostatka medicinske opreme, lijekova i sanitetskog materijala, opće poslijeratne oskudice te zbog mladog i neiskusnog kadra uspio je sa svojim najbližim suradnicima, uz velike napore, organizirati rad bolničke službe i s vremenom postaviti bolnicu "na noge" $i$ stvoriti solidnu osnovu za njezin daljnji razvoj.

Krajem četrdesetih i početkom pedesetih godina na odjele se primaju liječnici specijalizanti koji sredinom pedesetih postaju specijalisti. Približno u isto vrijeme na odjele se prima veći broj školovanih medicinskih sestara koje postaju glavne sestre bolnica i odjela.

Sredinom pedesetih godina Centralne bolničke laboratorije počinju voditi tek diplomirani magistri farmacije, biokemičari koji proširuju dijapazon laboratorijskih pretraga. Bolničke ljekarne vode magistri farmacije pod čijim 


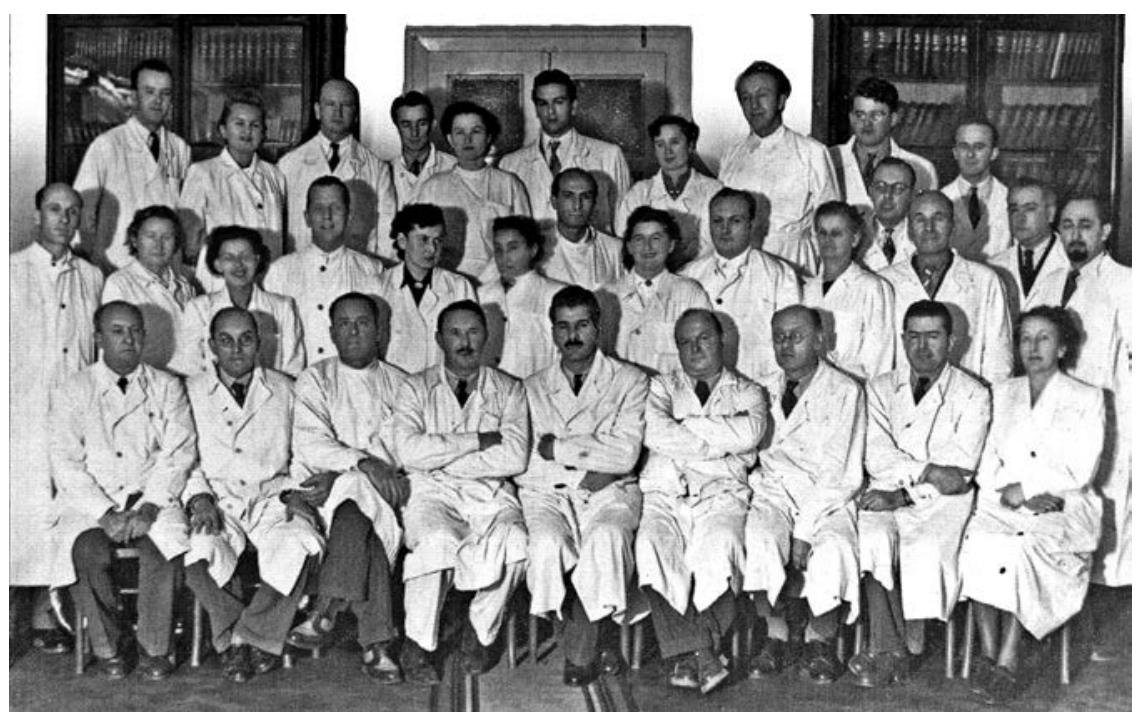

Slika 4. Liječnici Opće bolnice Rijeka, studeni 195I. Direktor bolnice prim. dr. Zdravko Kučić sjedi četvrti slijeva

vodstvom malobrojni farmaceutski tehničari rade galenske i magistralne pripravke, proizvode parenteralne lijekove, nabavljaju sanitetske materijale i gotove lijekove.

Krajem pedesetih godina osnivaju se Mikrobiološki laboratoriji koji postaju sastavni dijelovi centralnih bolničkih laboratorija (urinski, hematološki, biokemijski i mikrobiološki odsjek).

U riječkoj bolnici osnivaju se specijalnosti koje nisu postojale prije rata Neurologija, Ortopedija i Anesteziologija.

Ginekološko-porođajni odjel preseljen je 1946. iz riječke bolnice u konfisciranu i renoviranu zgradu bivšega Riječkog sanatorija (Sanatorio Fiumano).

Početkom I948. ukida se sušački Zarazni odjel. Bolesnici sa sušačkog Zaraznog odjela su nakon ujedinjenja Rijeke i Sušaka premješteni na riječki Zarazni odjel koji je od 1946. vodio primarijus dr. Walter Rukavina.

Ftizeološki odsjek riječkog Internog odjela premješta se 1949. u bolnicu za tuberkulozu pluća u Ičiće.

U bivšoj vili Miramare na Kostabeli osniva se početkom 1949. Dječja bolnica za liječenje koštano-zglobne tuberkuloze, u koju se premještaju bolesna djeca Ortopedske bolnice u Kraljevici. 


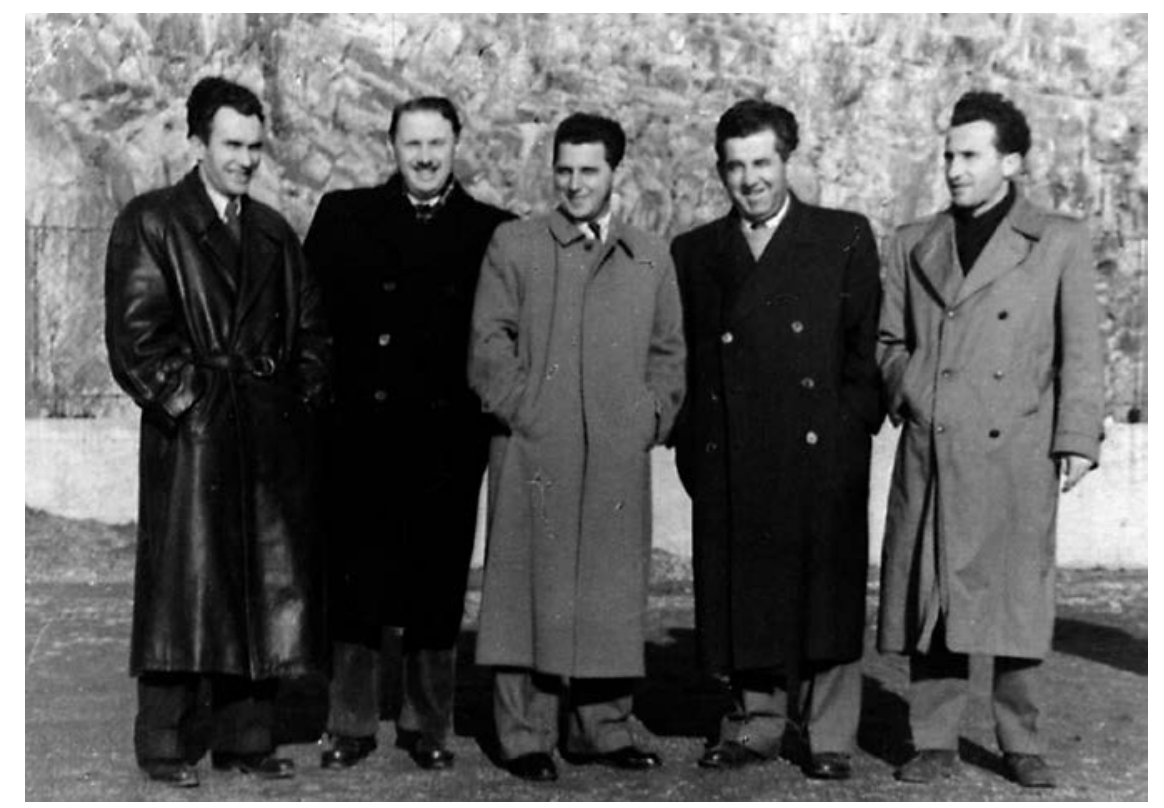

Slika 5. Uprava NK Kvarner - Rijeka, stadion Kantrida I954.

Dr. Zdravko Kučić drugi slijeva

Ortopedski odjel riječke bolnice premješta se 1956. u bivšu Vojnu bolnicu za koštano-zglobnu tuberkulozu u Lovranu i postaje civilna Ortopedska bolnica Lovran.

Otorinolaringološki odjel sušačke bolnice ukida se i96o. i formira se jedinstveni odjel u riječkoj bolnici.

Dječji odjel riječke bolnice i96r. preseljava u Dječju bolnicu na Kantridi u kojoj se postupno formiraju odjeli za klasičnu pedijatriju, dječju ortopediju, dječju kirurgiju i rehabilitaciju.

Revitaliziraju se klimatska lječilišta koja s vremenom postaju bolnice i nastavne baze Medicinskog fakulteta u Rijeci. Tako je i948. u Velom Lošinju otvoreno Dječje klimatsko lječilište za alergijske bolesti s odjelom za odrasle. Sudjelujući u radu Lječilišnog povjerenstva Ministarstva za narodno zdravlje RH, s ciljem da Opatija postane klimatsko lječilište, dr. Zdravko Kučić zaslužan je i za osnivanje Zavoda za rehabilitaciju i liječenje bolesti srca, pluća i reumatizma Thallassotherapija Opatija koji je otvoren I957. godine.

Aktivno sudjeluje u osnivanju Medicinskog fakulteta u Rijeci I955. godine. Po osnivanju fakulteta prima se veći broj specijalizanata, a dio specijalista postaju asistenti na katedrama Medicinskog fakulteta. 
Proširenje specijalističke kadrovske osnove, uz prijam školovanih medicinskih sestara, omogućilo je 1959 . otvaranje bolničkih specijalističkih ambulanata, a početkom 1960. na odjele se primaju i prve administrativne službenice.

Dvije godine nakon njegove smrti, 1963. otvara se novi Zavod za patologiju i patološku anatomiju, čiji je kamen temeljac na mjestu stare prosekture riječke bolnice postavljen 23. studenoga I959. godine.

Dr. Zdravko Kučić je u organiziranju i razvoju bolničkog zdravstva dao nezaobilazan doprinos ${ }^{2-4,10-13}$.

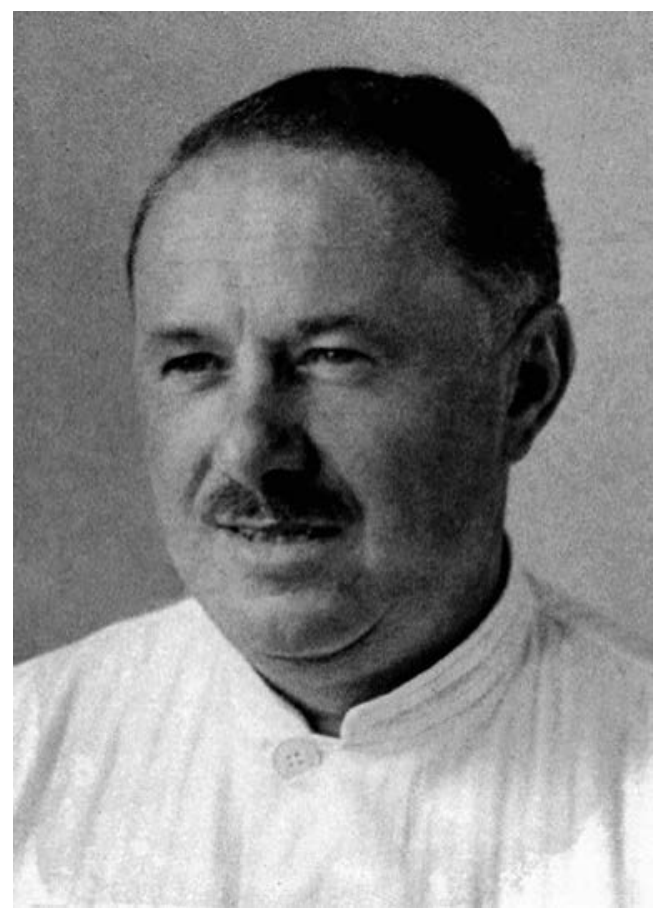

Slika 6. Prof. dr. Zdravko Kučić, jedna od posljednjih slika na poslu.

Poratna vremena tražila su i aktivno sudjelovanje u radu društveno-političkih organizacija pa je tako dr. Kučić bio potpredsjednik Narodnog odbora grada Rijeke, predsjednik Gradskog odbora Narodne fronte i predsjednik Okružnog odbora Narodne fronte za Hrvatsko primorje i Gorski kotar te dugogodišnji načelnik Zdravstveno-socijalnog odsjeka sušačkog i riječkog GNO-a. Jedan je od pokretača aktivnosti Riječke podružnice Zbora liječnika Hrvatske, njezin dugogodišnji tajnik (I8 godina), a jedno vrijeme i potpredsjednik Republičkog odbora Zbora liječnika Hrvatske. Bio je član Naučnomedicinskog savjeta Ministarstva narodnog zdravlja i Odbora za narodno zdravlje Izvršnog vijeća Sabora Hrvatske. U mladosti sportaš, jedno je vrijeme i predsjednik PVK Primorje i NK Kvarner - Rijeka [6-8,II,I3].

Kao dugogodišnji šef Internog odjela, direktor Opće bolnice Braća dr. Sobol (1949. - 196r.) i predsjednik Savjeta za narodno zdravlje i socijalnu politiku kotara Rijeke (1954.) jedan je od utemeljitelja riječkoga Medicinskog fakulteta. Na Katedri za internu medicinu od samog osnutka 1955. radi kao asistent, I958. habilitira na zagrebačkom Medicinskom fakultetu i postaje 


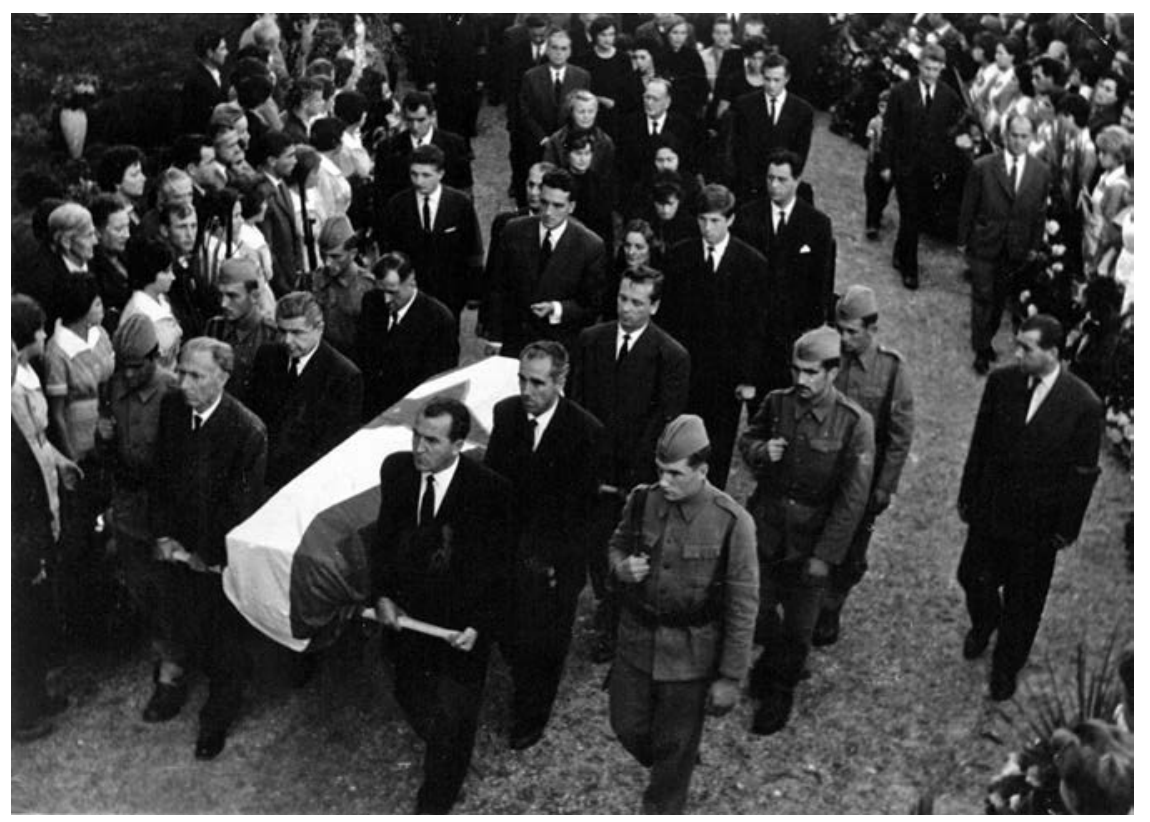

Slika 7. Pogreb dr. Zdravka Kučića na Trsatu 25. listopada ig6r. S lijeve strane kovčeg nose liječnici prof. dr. Silvije Novak, prof. dr. Dušan Jakac i dr. Kajetan Blečić, a s desne strane društveno-politički rukovoditelji grada i kotara Rijeke Kazimir Jelovica, Miloš Grbac i Nikola Pavletić.

naslovni docent (radnja Kardioaortalni lues), a u studenome I959. izabran je za izvanrednog profesora na Katedri [2,3].

U naponu snage, na pragu profesorske karijere i životnih ostvarenja, njegov snažni organizam nagrizla je teška bolest. Iscrpljen neizlječivom bolešću umro je u zoru 2r. listopada r96r. godine.

Bio je nosilac Ordena partizanske spomenice 194I. i brojnih ratnih i poslijeratnih odlikovanja i priznanja, među kojima se ističu Orden za hrabrost, Orden partizanske zvijezde II. reda, Orden rada II. reda, Orden bratstva i jedinstva II. reda i Orden zasluga za narod II. reda.

Osnivač je poslijeratne internističke službe u riječkoj bolnici i jedan od utemeljitelja poslijeratnoga riječkog bolničkog zdravstva [2,3,IO-I2].

Svog istaknutoga građanina na posljednje počivalište na Trsatsko groblje ispratilo je više od 20 ooo stanovnika Rijeke, Istre, Gorskog kotara i Hrvatskog primorja, uz najviše civilne i vojne počasti. Njegovu je jednostavnost, skromnost, poštenje, stručnost i nadasve humanost narod ovoga kraja znao cijeniti. Nakon njegove smrti, na prijedlog Kotarskog odbora 
Socijalističkog saveza radnog naroda, Općinska skupštine grada Rijeke odlučila je da od 1962. sušačka bolnica nosi njegovo ime. Bolnica je imala naziv Dr. Zdravko Kučić do integracije riječkih bolnica u Klinički bolnički centar I982., a i ulice na Sušaku na Gornjoj Vežici i u Njivicama na otoku Krku zovu se njegovim imenom [Io,I2].

\section{LiterATURA}

[1] Lukežić, Irvin, „Tvorci modernog Sušaka“, Sušačka revija br. 5, 1994., str. 13-16.

[2] Zgrablić, Milan, Korijeni i povijest interne medicine u Rijeci, Menora d. o. o. Rijeka, 1999., str. 448-449.

[3] Čohar, Franjo, „Katedra za unutarnje bolesti i nuklearnu medicinu“, u: Pavešić, Danilo ur., Medicinski fakultet u Rijeci, Medicinski fakultet Sveučilišta u Rijeci, Rijeka, 1997., str. 143-146.

[4] Novak, Silvije, „Historijat Internog odjela odnosno Interne klinike u Općoj bolnici „Dr. Zdravko Kučić“ u Rijeci od 1935. do 1970.“, Liječnički vjesnik, br. 7-8, 1986., str. 336-341.

[5] Sobolevski, Mihael - Urem, Mladen, „Dr. Zdravko Kučić - u povodu 50. obljetnice smrti“, Sušačka revija br. 76, 2011., str. 7180.

[6] Butorović, Radule, Sušak i Rijeka u NOB-i, Centar za historiju radničkog pokreta i NOR - a Istre, Hrvatskog primorja i Gorskog kotara, Rijeka, 1975., str. 102-142.

[7] Komar, Slavko, Sušački dani 1941., Centar za historiju radničkog pokreta i NOR-a Istre, Hrvatskog primorja i Gorskog kotara, Rijeka, 1986., str. 31-32.

[8] Kralj, Ivan, „Razvoj zdravstvene službe u Narodnooslobodilačkoj vojsci i na slobodnim teritorijima Hrvatske za vrijeme Narodnooslobodilačke borbe 1941. 1945.“, Saopćenja br. 26, god. 26, sv. 23., br. 1, str. 7-46, 1980., str. 7-47.

[9] Dakić, Mile, „Partizansko zdravstveno osoblje u bolnicama Petrove gore“, u: Petrova mi gora mati, Prosvjeta, Zagreb, 1976., str. 118-125.

[10] Novi list, god. 14., br. 247, Rijeka, 1961.

[11] Novi list, god. 14., br. 294, Rijeka, 1961.

[12] Narodni zdravstveni list, god. 4., br. 24, Rijeka 1961.

[13] Frković, Aleksandra - Bakašun Vjekoslav, Hrvatski liječnički zbor - Podružnica Rijeka 1947 - 2007., Hrvatski liječnički zbor - Podružnica Rijeka, Rijeka, 2007. 


\section{Summary}

Dr Zdravko Kučić was born in Bakar on II April I9Io. In I928 he finished the Gymnasium in Sušak and graduated from the School of Medicine, University of Belgrade in 1934. After completing the internship in Zagreb, he worked at the General Public Hospital "King Alexander I" in Sušak as a secondary doctor of medicine and later as an assistant at the Internal Department. In 1940 dr Kučić became the specialist of Internal medicine. Until August I943 he worked at Sušak and Rijeka Department of Internal Medicine.

Upon the unconditional surrender of fascist Italy in September 1943 dr Kučić joined the partisans in the National Liberation War (194I-1945) performing the most important duties at military sanitation departments.

After demobilization from the Yugoslav Army in January 1946, he was appointed Head of Internal and Infectious Diseases Department in General Hospital "Sušak" and in 1948 the Head of Department of Internal Medicine in General Hospital "Rijeka". In 1949 he was awarded the title "Primarius" of the Internal Medicine Department and the Director of the General Hospital "Rijeka".

Dr Kučić was a prominent figure on the political and social scene. Among many of his duties in the bodies of public authorities, he was also the head of the Healthcare and Social Welfare Committee in the City Council of Rijeka. For many years he was the main organizer of the post-war public hospital health in the City and County of Rijeka.

Dr Kučić was particularly responsible for the founding of the Faculty of Medicine in Rijeka in 1955. In 1958 he was elected as an assistant professor and in 1959 as an associate professor at the Department of Internal Medicine of the Faculty of Medicine, University of Rijeka. He died in Rijeka on 21 October 196r.

Keywords: Zdravko Kučić, history of medicine, 2oth century, Croatia, Sušak, Rijeka 